\title{
sciendo
}

\section{MAŁGORZATA POLZ-DACEWICZ}

\section{Nowy koronawirus - SARS CoV-2}

\section{Streszczenie}

Koronawirusy wywołują zakażenia u ssaków i ptaków. W grudniu 2019 r zarejestrowano w Chinach przypadki zapalenia płuc wywołane przez nieznany wcześniej czynnik. Nowy patogen nazwano SARS CoV-2, zaś chorobę COVID-19.

$\mathrm{W}$ artykule przedstawiono aktualne dane na temat nowego koronawirusa wywołującego pandemię w roku 2020. Omówiona została klasyfikacja wirusów należących do rodziny Coronaviridae, ich budowa oraz cykl replikacyjny. W dalszej części pracy opisano epidemiologię zakażenia, tj. źródło zakażenia, drogi szerzenia się zakażeń oraz objawy kliniczne. Kolejny podrozdział omawia najważniejsze aspekty laboratoryjnej diagnostyki zakażenia SARS CoV-2. Natomiast w ostatnim podrozdziale przedstawiono aktualny stan badań nad lekami stosowanymi w leczeniu choroby COVID-19 oraz próby opracowania skutecznej szczepionki profilaktycznej. Szczepionka w znaczący sposób wpłynie na zmniejszenie zapadalności i śmiertelności, gdyby wirus nadal krążył w populacji ludzkiej.

Słowa kluczowe: koronawirusy, SARS CoV-2, epidemiologia, leczenie, szczepionka.

DOI: $10.2478 /$ pjph-2019-0026

\section{WPROWADZENIE}

Wiele badań prowadzonych w ostatnich latach wykazało, że istnieje olbrzymia grupa wirusów zwierzęcych, które potencjalnie mogą przekroczyć barierę międzygatunkową. W związku z tym pojawienia się kolejnego odzwierzęcego koronawirusa zakażającego człowieka można się było spodziewać.

\section{Rys historyczny}

Koronawirusy znane są od dawna. Zakażać mogą ptaki i ssaki, wywołując u nich choroby układu oddechowego, nerwowego, narządów wewnętrznych i przewodu pokarmowego, m.in. zakaźne zapalenie otrzewnej u kotów, epidemiczną biegunkę świń, wirusowe zapalenie żołądka i jelit u bydła czy zakaźne zapalenie oskrzeli u ptactwa [1].

Pierwsze wzmianki o ludzkich koronawirusach pochodzą z lat 60., kiedy wyizolowano i opisano dwa patogeny - HCoV-229E oraz HCoV-OC43 - wywołujące zakażenia układu oddechowego. Przez wiele lat pozostawały one jedynymi
Novel coronavirus - SARS CoV-2 
W 2012 roku, po 10 latach od epidemii SARS-CoV, zanotowano zachorowania na nową chorobę układu oddechowego wywoływaną przez koronawirus MERS (ang. middle east respiratory syndrome Coronavirus) [3]. Wirus MERS-CoV po raz pierwszy rozpoznano u pacjenta z Arabii Saudyjskiej. Ze względu na podobieństwo na poziomie genetycznym i funkcjonalnym (m.in. wykorzystanie tego samego receptora komórkowego) do wirusów występujących u nietoperzy uznano, że sa one naturalnym gospodarzem i rezerwuarem wirusa, zaś ogniwem pośrednim mogą być wielbłądy jednogarbne (Camelius dromedarius), u których stwierdzono wysokie miana swoistych przeciwciał neutralizujących oraz wirusowe RNA. Nie doszło wówczas do wybuchu pandemii, jednak wirus krąży w populacji.

W styczniu 2019 roku zanotowano w mieście Wuhan, prowincji Hubei w Chinach zachorowania spowodowane nieznanym dotąd wirusem. Choroba szybko rozprzestrzeniła się wywołując epidemię, a następnie pandemię. Początkowo nazwano go nowym koronawirusem 2019 (2019 novel coronavirus; 2019-nCoV) [4].

Badania wykazały, że jest to nowy typ koronawirusa, spokrewniony z wirusem SARS, stąd przez International Virus Classification Commission (ICTV) został nazwany SARS-CoV-2, zaś chorobę przez niego wywołaną WHO nazwała COVID-19.

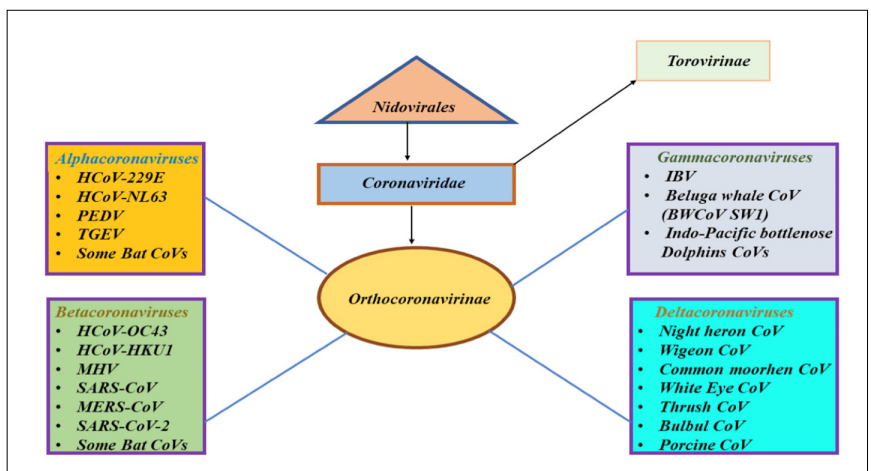

RYCINA 1. Klasyfikacja koronawirusów (wg Ashour).

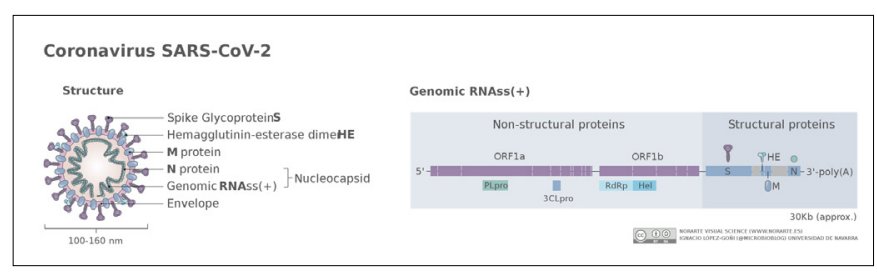

RYCINA 2. Budowa SARS CoV-2 i struktura genomu.

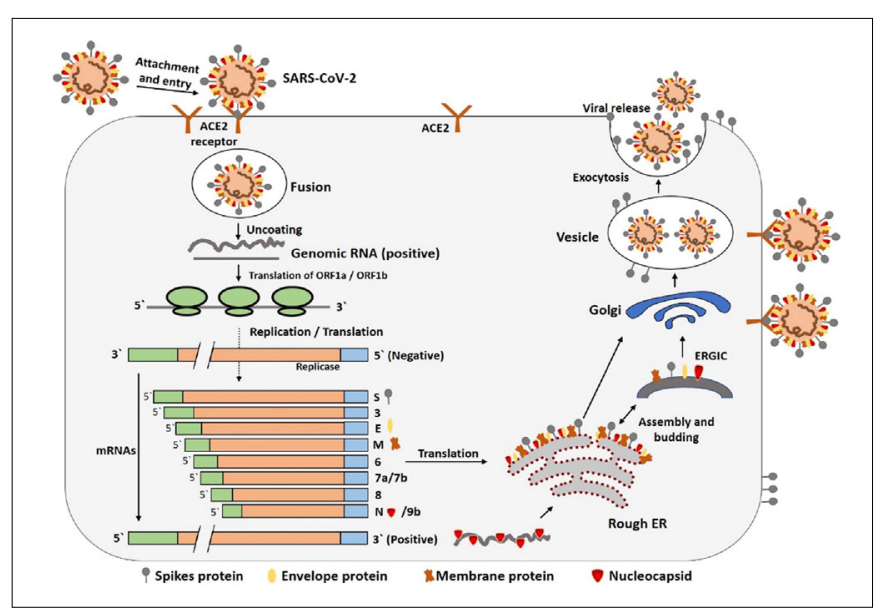

RYCINA 3. Cykl replikacyjny SARS CoV-2 (wg Shereen).

\section{CORONAVIRIDAE - charakterystyka rodziny koronawirusów}

Wirus (łac. virus - trucizna) jest tworem bezkomórkowym. Cząstka wirusa składa się z kwasów nukleinowych (DNA lub RNA oraz osłonki białkowo-lipidowej). Kwasy nukleinowe decydują o tym, że wirus może się namnażać, ale wyłącznie w żywych komórkach, wykorzystując jej „,aparaturę" do powielania własnego kwasu nukleinowego i syntezy białka. Wirus posiada osłonkę białkową potrzebną mu do tego, aby przyczepić się do powierzchni zakażanej komórki.

Wirus do wnętrza gospodarza wnika przez błony śluzowe jamy ustnej, górnych dróg oddechowych oraz spojówek. Ryzyko zakażenia wzrasta wraz z czasem ekspozycji oraz liczbą cząstek wirusowych dostających się do wrażliwego organizmu.

Koronawirusy według klasyfikacji Baltimore’a należą do IV grupy wirusów. Ich materiał genetyczny stanowi jednoniciowy, niesegmentowany RNA o dodatniej polarności $(+)$ ssRNA. Wirusy RNA wymagają polimerazy RNA zależnej od RNA (RdRp) do transkrypcji i replikacji genów wirusowych. Podczas syntezy nici RNA częstość popełnianych błędów jest znacznie wyższa niż przy syntezie nici DNA, ponieważ nie mają one systemu korygującego błędy tzw. proofreading. Podczas replikacji może dochodzić także do przeskoku polimerazy na nić sąsiednią oraz do rekombinacji nici. Powoduje to powstawanie różnej populacji wirusów, których sekwencje genomu są inne niż sekwencja nici macierzystej (ang. quasi-species) [5]. Zmiany te mogą powodować powstawanie nowych szczepów wirusa o odmiennych właściwościach antygenowych.

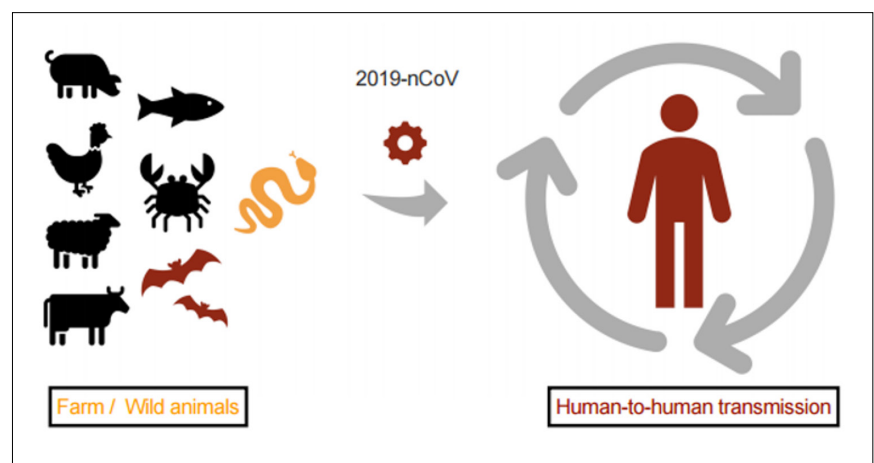

RYCINA 4. Ewolucja koronawirusów [19].

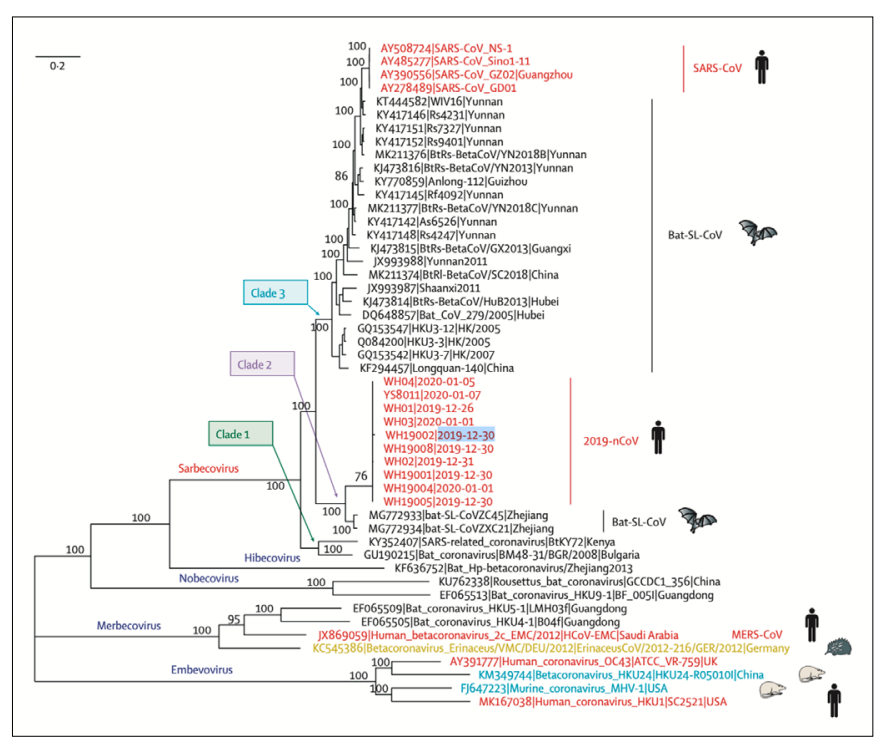

RYCINA 5. Filogenetyczna analiza genomu 2019-nCoV [4]. 
Jest to jeden z mechanizmów obronnych wirusa przed działaniem układu odpornościowego zakażanego organizmu.

Rodzina Coronaviridae składa się z dwóch odrębnych podrodzin: Coronavirinae i Torovirinae. Na podstawie cech genetycznych podrodzinę Coronavirinae podzielono na cztery rodzaje: alfa-, beta-, delta- oraz gamma-koronawirusy [6-8]. Klasyfikacja koronawirusów została przedstawiona na rycinie 1. Z medycznego punktu widzenia najważniejsze są wirusy grupy alfa i beta, do których należą wszystkie znane gatunki zakażające człowieka. Sześć zostało wcześniej zidentyfikowanych tj. HCoV-NL63 and HCoV-229E, należące do Alphacoronavirus; oraz HCoV-OC43, HCoV-HKU1, SARS-CoV i MERS-CoV należące do rodzaju Betacoronavirus.

Koronawirusy są jednymi z największych wirusów RNA pod względem długości genomu (26 000-32 000 nukleotydów) oraz rozmiaru wirionu (sferyczny, $80-180 \mathrm{~nm}$ średnicy). Wirus posiada osłonke lipidową. Genom wirusa koduje 16 białek niestrukturalnych oraz białka strukturalne [4]. Główne białka strukturalne to glikoproteina powierzchniowa $\mathrm{S}$, małe białko osłonki E, białko błonowe $\mathrm{M}$ oraz białko nukleokapsydu N. Powierzchniowa glikoproteina $\mathrm{S}$ odgrywa kluczową role w adsorpcji wirusa do powierzchni komórki i determinuje jego tropizm (powinowactwo). Budowę wirusa przedstawia rycina 2 , zaś cykl replikacyjny rycina 3.

Nowy koronavirus SARS-CoV-2 (2019-nCoV) należy do rodziny Coronaviridae i ma budowę podobną do pozostałych przedstawicieli tej rodziny. Badania wykazały, że SARS-CoV-2 zawiera sekwencje w $50 \%$ podobne do MERS-CoV, w $79 \%$ do SARS-CoV i w $88 \%$ do koronawirusów wyizolowanych z nietoperzy.

\section{Epidemiologia choroby COVID19}

Źródłem zakażenia jest człowiek. Na rycinie 4 przedstawiono krążenie wirusów w populacji zwierząt i możliwość zakażenia człowieka. SARS-CoV-2 przenosi się głównie drogą powietrzno-kropelkową, a także pokarmowo-wodną (9-12). Okres wylegania choroby wynosi ok. 5 dni a może być dłuższy nawet do 24 dni. Stąd osoby z kontaktu z chorym muszą być poddane kwarantannie przez okres nie krótszy niż czas wylęgania choroby. U ok. $80 \%$ chorych choroba przebiega łagodnie lub nawet bezobjawowo, u 15\% z objawami średnio-ciężkimi a tylko u ok. 5\% ma ciężki przebieg kliniczny z możliwością rozwoju niewydolności wielonarządowej i zgonu.

Białko wypustki S SARS-CoV i MERS-CoV przyłączają się do różnych receptorów na powierzchni komórek gospodarza (receptor-binding domains -RBDs). SARS-CoV jako głównego receptora używa enzym konwertujący angiotensynę 2 (ACE2) oraz CD209L jako receptora alternatywnego, podczas gdy MERS-CoV wykorzystuje jako pierwotnego receptora dipeptydylopeptydaza 4 (DPP4, znany także jako CD26).

Badacze próbują obecnie poznać wzorzec mutacji SARS-CoV-2 przez analizę częstości mutacji, co pozwoli na poznanie zdolności ewolucyjnej tego wirusa. Ma to znaczenie nie tylko z punktu widzenia klasyfikacji wirusa, ale także poznania jego patogenności.

Analiza filogenetyczna całych genomów różnych szczepów izolowanych od pacjentów wykazała, że 2019-nCoV należy do tego samego kladu (klad - zbiór organizmów mających wspólnego przodka) - Betacoronavirus jak MERS-CoV, SARS-like bat CoV i SARS-CoV, jednak ma większe podobieństwo do SARS-like bat CoV a mniejsze do MERS-CoV [4]. Analiza sekwencji aminokwasowych może rzucić nowe światło jak dalece ten wirus strukturalnie i funkcjonalnie odmienny jest od SARS-CoVs. Dlatego też dalsze badania są konieczne. Filogenetyczną analizę genomu 2019-nCoV obrazuje rycina 5 .

\subsection{Kryteria rozpoznania choroby COVID-19 (wg 13)}

\section{Przypadek podejrzany}

Podstawą do postawienia podejrzenia COVID-19, uzasadniającego wykonanie badań wykrywających materiał genetyczny SARS-CoV-2 jest spełnienie warunków zawartych w punkcie 1 i 2 :

1. Ostra infekcja dróg oddechowych o nagłym początku i przynajmniej jednym z objawów: gorączka, kaszel, duszność lub wykrycie przeciwciał w badaniu serologicznym.

2. a) w wywiadzie występuje podróż lub pobyt w ostatnich 14 dniach licząc od poczatku choroby do kraju/regionu, w którym odnotowano lokalną transmisję zakażenia SARS-CoV-2; b) bliski kontakt $\mathrm{z}$ potwierdzonym lub prawdopodobnym przypadkiem COVID-19 w ostatnich 14 dniach; c) ciężki stan wymagający hospitalizacji przy braku innej etiologii mogącej tłumaczyć obraz kliniczny.

Jeżeli jednak zostanie udokumentowana transmisja lokalna na danym obszarze, to wówczas wymagane jest spełnienie tylko warunków zawartych w punkcie 1 . Oznacza to, że wszyscy pacjenci z objawami ostrej infekcji oddechowej stwierdzanej podczas pierwszego kontaktu z opieką zdrowotną (w podstawowej opiece zdrowotnej lub w szpitalu o jakimkolwiek profilu) powinni być traktowani jako przypadki podejrzane, a więc poddani badaniu potwierdzającemu zakażenie.

\section{Przypadek prawdopodobny}

Rozpoznanie COVID-19 jest prawdopodobne, gdy u osoby z objawami ostrej infekcji oddechowej wynik badania materiału genetycznego SARS-CoV-2 przeprowadzonego techniką RT PCR jest wątpliwy lub niejednoznaczny, lub gdy wynik badania RT PCR materiału genetycznego koronawirusów (pan-coronavirus test) jest dodatni.

\section{Przypadek potwierdzony}

Jest to każda osoba $\mathrm{z}$ laboratoryjnym potwierdzeniem zakażenia SARS-CoV-2 techniką RT-PCR niezależnie od obecności objawów klinicznych.

\section{Diagnostyka laboratoryjna zakażeń SARS CoV-2 (metody identyfikacji wirusa $w$ materiale od pacjentów)}

Laboratoria wykonujące badania w kierunku zakażenia koronawirusem funkcjonują $\mathrm{w}$ określonym systemie prawnym i muszą stosować metody badawcze zgodne z aktualnym stanem wiedzy medycznej. Laboratoria muszą zatem spełniać określone standardy oraz stosować się do rekomendacji organów uprawnionych do ich wydawania. Obecną sytuację epidemiologiczną nadzoruje resort zdrowia i Główny Inspektor Sanitarny, a rekomendacje dla diagnostów laboratoryjnych wydaje konsultant krajowy w dziedzinie mikrobiologii lekarskiej.

Zgodnie z rekomendacjami WHO w diagnostyce zakażeń SARS-CoV-2 powinny być stosowane metody biologii molekularnej, gdyż tylko te metody pozwalają na spełnienie laboratoryjnego kryterium potwierdzenia przypadku COVID-19, zgodnie z obowiązującą definicją przypadku na potrzeby nadzoru nad zakażeniami ludzi nowym koronawirusem [14-17].

Testy serologiczne tradycyjne lub też tzw. szybkie testy kasetkowe na podstawie pobranej próbki krwi nie mają tak dużej 
wiarygodności. Poza tym można otrzymać sporą liczbę wyników fałszywie ujemnych. Należy także brać pod uwagę możliwość, że badana osoba może także znajdować się w okresie tzw. okna serologicznego (kiedy organizm nie wytworzył jeszcze przeciwciał) i w tym czasie są nosicielami tego wirusa i zakażają inne osoby. Może to być niebezpieczne nie tylko dla samego zakażonego, ale także całego systemu ochrony zdrowia.

Testy serologiczne natomiast wykrywają w surowicy obecność przeciwciał. W każdym zakażeniu układ immunologiczny człowieka odpowiadając na antygen wytwarza przeciwciała najpierw klasy IgM a później IgG. W przypadkach niektórych patogenów czas pojawiania się przeciwciał jest znany. Wiadomo, że pojawią się np. w piątej dobie od zakażenia. Jednak w przypadku koronawirusa SARS-CoV-2 nie wiadomo jeszcze dokładnie, kiedy to następuje. Epidemia na świecie trwa od grudnia 2019 roku. Jest to czas zbyt krótki, aby w pełni poznać charakterystykę wirusa.

Materiałem do badania jest najczęściej wymaz z nosogardzieli lub gardła. Badania przeprowadza się metodami biologii molekularnej według zaleceń WHO, CDC w Atlancie (USA) oraz Krajowej Izby Diagnostów Laboratoryjnych.

W pierwszej fazie badania dokonuje się izolacji materiału genetycznego z próbki klinicznej pobranej od pacjenta. W etapie drugim (detekcja) wykrywa się obecność genów badanego koronawirusa metodą PCR. Test jest dodatni jeśli stwierdzi się obecność genu ORF1ab i/lub genów N i E.

Badanie, w zależności od rodzaju aparatury diagnostycznej danego laboratorium, może trwać od 2,5 godz. (w tzw systemie zamkniętym) do 6-8 godzin, gdy reakcja PCR musi być poprzedzona izolacją manualną wirusowego kwasu nukleinowego. Czasem oznaczenie trzeba powtórzyć, kiedy diagnosta wykonujący badanie ma wątpliwości dotyczące interpretacji uzyskanych wyników.

\section{Terapia i profilaktyka}

\subsection{Badania nad lekami}

Badania nad lekami prowadzone są w trzech kierunkach a ich wybór opiera się głównie na doświadczeniach z epidemii SARS-CoV [18-20]. W walce $\mathrm{z}$ nowym koronawirusem naukowcy biorą pod uwagę trzy strategie opracowania nowych leków. Pierwszy to przebadanie skuteczności już istniejących szeroko wachlarzowych leków przeciwwirusowych jak interferony i ribawiryna. Zaletą tych terapii jest znany metabolizm leków, ich dawkowanie, skuteczność czy działania niepożądane. Wadą zaś może okazać się zbyt szerokie spektrum co będzie przyczyną nieskuteczności w leczeniu zakażenia spowodowanego SARS-CoV-2. Drugim kierunkiem poszukiwań jest wykorzystanie istniejących molekularnych baz danych do znalezienia cząsteczek wykazujących efekt terapeutyczny wobec koronawirusa, m.in. próbuje się zastosować remdesivir oraz lopinavir i ritonavir - leki skuteczne i zatwierdzone w leczeniu zakażeń HIV. Wreszcie trzecia strategia oparta na informacji o strukturze genomu różnych koronawirusów i poszukiwaniu nowych punktów uchwytu dla leków przeciw koronawirusom. Teoretycznie leki opracowane w ten sposób mogą mieć większy efekt terapeutyczny jednak procedura ich opracowania może trwać zbyt długo.

Światowa Organizacja zdrowia opracowała tzw. program solidarnościowy (solidarity program), który zaleca następujące leczenie COVID 19 [21]:

1. Zwyczajową terapię danego kraju;
2. terapię eksperymentalną - remdesivir (pierwotnie przeznaczoną do leczenia zakażeń wirusem Ebola) - ssRNA;

3. Skojarzoną terapię dwóch leków antyretrowirusowych (HIV/AIDS) - lipinavir+ritonavir;

4. Jak wyżej uzupełniona podawaniem silnego immunomodulatora (IFN $\beta$ );

5. Stosowanie leków przeciwmalarycznych (chlorochina, hydroksychlorochina);

6. Tzw. terapia „marsylska” - leki przeciwmalaryczne w skojarzeniu z antybiotykiem - azytromycyną.

\subsection{Badania nad szczepionkami}

Obecnie nie ma dostępnej szczepionki profilaktycznej w zakażeniach SARS-CoV-2. Idealna szczepionka profilaktyczna powinna spełniać następujące kryteria:

- jednorazowa dawka;

- trwała odpowiedź (na całe życie);

- pełna odporność u 100\% szczepionych;

- brak działań niepożądanych;

- niska cena (możliwość powszechnego stosowania).

Prace nad przygotowaniem szczepionki są długotrwałe i składają się z dwóch podstawowych etapów, tj. badań przedklinicznych oraz badań klinicznych. W badaniach przedklinicznych musi zostać zidentyfikowany patogen odpowiadający za daną chorobę. Następnie należy określić jaki element wirusa (antygen) będzie głównym składnikiem szczepionki. Wreszcie w hodowli komórek in vitro, następnie na zwierzętach ocenia się bezpieczeństwo i immunogenność szczepionki. To znaczy czy nie jest ona toksyczna i czy jej podanie powoduje wytworzenie przeciwciał odpornościowych.

W badaniach na zwierzętach określa się bezpieczną dawkę szczepionki oraz metodę jej podania. Po pozytywnym zakończeniu etapu przedklinicznego przystępuje się do badań klinicznych na ludziach.

Badania kliniczne obejmują trzy fazy. W I fazie (grupa kilkudziesięciu dorosłych osób - ochotników) ocenia się bezpieczeństwo szczepionki, rodzaj i zakres odpowiedzi immunologiczne.

Gdy wyniki fazy I są obiecujące rozpoczyna się II faza badań klinicznych (grupa ochotników - kilkaset osób). Badane jest bezpieczeństwo szczepionki, immunogenność, proponowane dawki, harmonogram szczepienia i metody podania szczepionki. Są to badania randomizowane (losowy przydział ochotników do poszczególnych grup badawczych), przy czym jedna z grup otrzymuje placebo (grupa kontrolna). Pozytywne wyniki tego badania pozwalają na przejście do III fazy badań klinicznych (tysiące do dziesiątek tysięcy ludzi). Są to badania randomizowane prowadzone metodą podwójnie ślepej próby, tzn. ani ochotnicy, ani lekarze podający preparat nie wiedzą czy danej osobie podawana jest szczepionka czy placebo. Celem III fazy jest ocena bezpieczeństwa szczepionki w dużej grupie ludzi, zwłaszcza pod kątem występowania rzadkich działań niepożądanych, które mogły nie być wykryte we wcześniejszych etapach badań. Badania nad opracowaniem szczepionek przeciwko SARS-CoV-2 prowadzi wiele ośrodków na świecie [22].

W chwili obecnej testowane są szczepionki oparte na bazie kwasów nukleinowych (RNA lub DNA) kodujące białka strukturalne wirusa (wchodzące w skład kapsydu cząsteczki wirusowej), wykorzystujące niereplikujący się wektor wi- 
rusowy jako drogę dostarczenia antygenów do organizmu, szczepionki „żywe” atenuowane (pozbawione zjadliwości), inaktywowane, podjednostkowe (zawierające wybrany antygen wirusa).

Obecnie kilka firm prowadzi badania nad szczepionką mRNA. Technika opracowania takiej szczepionki jest dość prosta. Bowiem wirus zakażając komórkę produkuje wirusowe mRNA, na bazie którego następuje synteza białek wirusowych. Znając sekwencje RNA wirusa możemy zsyntetyzować dany odcinek mRNA wirusa kodujący białko, przeciw któremu nasz organizm wytwarza przeciwciała. Następnie taki fragment RNA umieszcza się w małych cząsteczkach liposomowych, tzw. nanocząsteczkach. Szczepionki mRNA mają wiele zalet, m.in. brak ryzyka wbudowania tego RNA do genomu osoby zaszczepionej, mRNA jest nietrwałe i szybko zostaje usunięte $\mathrm{z}$ organizmu. Ponadto produkcja szczepionki trwa stosunkowo krótko (6-8 tygodni). Możliwość jej przechowywania w temperaturze $37^{\circ} \mathrm{C}$ przez kilka tygodni zmniejsza koszty magazynowania i transportu.

Najbardziej zaawansowane badania prowadzi firma Moderna, której szczepionka roboczo została nazwana mRNA-1273. Szczepionka ta wykorzystuje glikoproteinę powierzchniową $\mathrm{S}$ składającą się z dwóch części S1 i S2. Częsś S1 tworzy główkę $i$ odgrywa rolę domeny rozpoznającej receptory na powierzchni komórki gospodarza. Trwają badania kliniczne, których wyniki mają być znane w lipcu bieżącego roku. Szczepionka jednak nie wpłynie już na pierwszą falę pandemii. Natomiast może być użyteczna w późniejszym okresie, po pandemii, zwłaszcza gdyby wirus krążył w populacji sezonowo.

\section{ZAKOŃCZENIE}

Minęły zaledwie 4 miesiące od zarejestrowania pierwszych przypadków zakażeń SARS CoV-2. Wiele o tym wirusie już wiadomo. Stale trwają badania a liczba publikacji na ten temat systematycznie wzrasta. Jednakże istnieje jeszcze wiele pytań i zagadnień wymagających rozwiązania.

Badania przeprowadzone $\mathrm{w}$ uniwersytecie $\mathrm{w}$ Pittsburgh (USA) wykazały występowanie mutacji i delecji w kodujących i niekodujących fragmentach genomu wirusa SARS-CoV-2. Obserwacje te rzucają światło na genetyczne zróżnicowanie i szybką ewolucję tego nowego wirusa [23]. Wykazano także, że populacja wirusów SARS CoV-2 krążących obecnie jest zróżnicowana na co najmniej 16 genotypów, spośród których 6 genotypów jest w znacznej przewadze [24]. Ewentualne mutacje w powierzchniowej glikoproteinie S mogłyby indukować zmiany prowadzące $\mathrm{w}$ konsekwencji do zmiany antygenowości wirusa [25]. Mogłoby to stanowić implikacje dla opracowania skutecznych leków a także profilaktycznej szczepionki. Następne badania są zatem konieczne do poznania natury wirusa i opracowania strategii diagnostycznych, terapeutycznych oraz potencjalnych mechanizmów oporności na chemioterapeutyki stosowane $\mathrm{w}$ terapii tego zakażenia.

\section{PIŚMIENNICTWO}

1. Kahn JS, McIntosh K. History and recent advances in coronavirus discovery. Pediatr Infect Dis. 2005;24:223-7.

2. Zhong N, Zheng BY, Li Y, et al. Epidemiology and cause of severe acute respiratory syndrome (SARS) in Guangdong. People's Republic of China, in February, 2003. Lancet. 2003;362(9393):1353-8.
3. Wang N, Shi L, Zhang S, et al. Structure of MERS-CoV spike receptor-binding domain complexed with human receptor DPP4. Cell Res. 2013;23:986-90.

4. Lu R, Zhao X, Li J, et al. Genomic characterisation and epidemiology of 2019 novel coronavirus: implications for virus origins and receptor binding. Lancet. 2020;395:565-74.

5. Lauring AS, Andino R. Quasispecies theory and the behavior of RNA viruses. PLoS Pathog. 2010;6:e1001005.

6. Shereen A, Khan S, Kazmi A, et al. COVID-19 infection: Origin, transmission, and characteristics of human coronaviruses. J Advanc Res. 2020;24:91-8.

7. Ashour H, Elkhatib W, Rahman M, et al. Insights into the Recent 2019 Novel Coronavirus (SARS-CoV-2) in Light of Past Human Coronavirus Outbreaks. Pathogens. 2020;9:186.

8. Fung TS, Liu DX. Human coronavirus: host-pathogen interaction. Annu Rev Microbiol. 2019;73:529-57.

9. Lin X, Gong Z, Xiao Z, et al. Novel coronavirus pneumonia outbreak in 2019: Computed tomographic findings in two cases. Korean J Radiol. 2020;21(3):365-8.

10. Velavan TP, Meyer C. The Covid-19 epidemic. Tropical Med Int Health 2020;25(3):278-80.

11. Zhu, N, Zhang D, Wang, et al. Investigating, China Novel Coronavirus, 2019. Research Team. A novel coronavirus from patients with pneumonia in China. N Engl J Med. 2020;382(8):727-33.

12. Guan W, Ni Z, Hu Y, et al. Clinical characteristics of coronavirus disease 2019 in China. N Engl Med. 2020; 382:1708-20.

13. Definicja przypadku na potrzeby nadzoru nad zakażeniami ludzi nowym koronawirusem SARS-CoV-2. GIS; www.gis.gov.pl.

14. Phan T. Novel coronavirus: from discovery to clinical diagnostics. Infect. Genet Evol. 2020;79;104211.

15. Nishiura H, Linton NM, Akhmetzhanov AR. Initial cluster of novel coronavirus (2019-nCoV) infections in Wuhan, China is consistent with substantial human-to-human transmission. J Clin Med. 2020;9(2):488.

16. Yu F, Du L, Ojcius DM, Pan C, Jiang S. Measures for diagnosing and treating infections by a novel coronavirus responsible for a pneumonia outbreak originating in Wuhan, China. Microbes Infect. 2020;22(2):74-9.

17. Loeffelholz MJ, Tang YW. Laboratory diagnosis of emerging human coronavirus infections - the state of the art. Emerg Microbes Infect. 2020;9(1):747-56

18. Guangdi L, De Clercq E. Therapeutic options for the 2019 novel coronavirus (2019-nCoV). Nat Rev Drug Discov. 2020;19:149-50.

19. Wu C, Liu Y, Yang, et al. Analysis of therapeutic targets for SARS-CoV-2 and discovery of potential drugs by computational methods. APSB. 2020;10(5):766-88.

20. Wang, M, Cao R, Zhang L, et al . Remdesivir and chloroquine effectively inhibit the recently emerged novel coronavirus $(2019-\mathrm{nCoV})$ in vitro. Cell Res. 2020;30:269-71.

21. Solidarity clinical trial for COVID-19 treatments. WHO, www.who.int

22. Amant F, Krammer F, SARS CoV-2 Vaccines: Status Report. Immunity 2020; doi: 10.1016/j.immuni.2020.03.007 [Epub ahead of print].

23. Phan T. Genetic diversity and evolution of SARS-CoV-2. Infect Genet Evol. 2020;81:104260.

24. Morais IJ Jr, Polveiro RC, Souza GM, et al. The global population of SARS-CoV-2 is composed of six major subtypes. bioRxiv. https:// doi.org/ 10.1101/ 2020.04.14.040782.

25. Pachetti M, Marini B, Benedetti F, et al. Emerging SARS-CoV-2 mutation hot spots include a novel RNA-dependent-RNA polymerase variant. J Transl Med. 2020;18:179,

Adres do korespondencji

Prof. dr hab. Małgorzata Polz-Dacewicz

Zakład Wirusologii z Laboratorium SARS, Uniwersytet Medyczny w Lublinie

ul. Chodźki 1, 20-093 Lublin

E-mail:m.polz@umlub.pl

Praca przyjęta do druku: 28.04 .2020

Praca zaakceptowana do druku: 05.05.2020 